\title{
Pusat Rehabilitasi Gangguan JiWa dan Skizofrenia dengan Pendekatan Arsitektur Perilaku di Kabupaten Kulonprogo
}

\author{
Annisa Mutia Sari, Musyawaroh, Wiwik Setyaningsih \\ Program Studi Arsitektur \\ Fakultas Teknik \\ Universitas Sebelas Maret Surakarta \\ Email : annisamutia22@gmail.com
}

\begin{abstract}
Psychiatric disorder sufferers in Indonesia is increasing every year. This also happens in the Daerah Istimewa Yogyakarta which is the province with the largest number of psychiatric sufferers in Indonesia. The phenomenon of the increasing psychiatric sufferers happen due to the lack of mental health services and facilities so that many sufferers of psychiatric disorders that have not been handled properly. The problem that arise in the design of Psychiatric Disorder and Schizophrenia Rehabilitation Center is how to create the design of rehabilitation center that accomodates the activities and needs of sufferers both physically and mentally based on behavior that indicated the sufferers. The goal is to get the container activities and needs that play a role in the healing of sufferers psychologically, socially, and spiritually with Behaviorism Architecture as the design concept. The methods used in the design of Psychiatric Disorder and Schizophrenia Rehabilitation Center is Behaviorism Concept. This concept was applied in architectural elements focused on three aspects, namely, privacy, comfort, and security. The application of the Behaviorism concept aims to meet the appropriate design in accordance with the surferrers' behavior wihich is realized through optimization of potential site and the zonning concept. The basic form of the building is a square shape in combination with pyramid roof and sloping roof to get a homey impression. Likewise, the look of the building is made simple, but it capable to display the principles of Behaviorism Architecture.
\end{abstract}

Kata kunci: Behavior Architecture, Psychiatric Disorders, Rehabilitation Center, Schizophrenia

\section{PENDAHULUAN}

Kesehatan jiwa masih menjadi persoalan serius di Indonesia. Kemajuan teknologi dan perubahan pola hidup yang tiba-tiba menjadi salah satu hal yang menyebabkan perilaku menyimpang yang mengarah pada masalah kesehatan jiwa. Berdasarkan Data Riset Kesehatan Dasar (Pemerintah Daerah Istimewa Yogyakarta, 2013) tercatat prevalensi gangguan jiwa berat di Indonesia mencapai 1,7 per mil, artinya 1-2 orang dari 1.000 penduduk di Indonesia mengalami gangguan jiwa berat dengan prevalensi tertinggi adalah Propinsi D.I.Yogyakarta (2,7 permil).

Tingginya penderita gangguan jiwa di DIY disebabkan karena fasilitas dan pelayanan kesehatan jiwa yang masih sangat minim. DIY hanya memiliki dua fasilitas kesehatan jiwa, yaitu Rumah Sakit Jiwa Ghrasia dan Rumah Sakit Puri Nirmala dengan daya tampung yang tidak sebanding dengan pasiennya. Fakta ini diperkuat dalam Profil Rumah Sakit Jiwa Ghrasia (Pemerintah Daerah Istimewa
Yogyakarta, 2013) yang mengatakan bahwa hanya 568 orang atau $41,86 \%$ penderita gangguan jiwa yang telah teridentifikasi, sedangkan 58,14\% sisanya belum diketahui.

Fasilitas dan pelayanan kesehatan jiwa yang ada di DIY saat ini juga belum diimbangi dengan tenaga kesehatan profesional yang memadai dan tidak sesuai dengan standar fasilitas kesehatan jiwa sehingga membuat pemulihan tidak berjalan dengan optimal baik secara mental maupun fisik. Banyak penderita gangguan jiwa yang kondisinya semakin memburuk dikarenakan tidak mendapatkan perawatan yang layak dan sesuai dengan kebutuhan mereka.

Penderita gangguan jiwa memerlukan wadah yang mampu menyediakan proses pemulihan baik secara fisik maupun mental yang dapat memberikan perasaan aman, nyaman, privasi, dan dapat mengarahkan perilaku penderita secara teratur dan terarah sehingga kondisi penderita dapat berangsur membaik. 
Oleh karena itu, dibutuhkan pendekatan Arsitektur Perilaku untuk dapat menciptakan sebuah keadaan yang sesuai dengan kebutuhan penderita. Penerapan Arsitektur Perilaku dalam rancangan akan mempengaruhi tingkah laku, persepsi, dan perasaan yang muncul dari masing-masing pelaku kegiatan.

\section{METODE}

Metode yang digunakan dalam Perancangan Pusat Rehabilitasi Gangguan Jiwa dan Skizofrenia ini menggunakan pendekatan Arsitektur Perilaku. Arsitektur Perilaku merupakan bagian dari Psikologi Arsitektur. Pendekatan ini berfokus pada hubungan antara perilaku manusia dengan lingkungan binaannya (Gifford, 2007).

Metode yang diambil dari pendekatan Arsitektur Perilaku terdiri dari tiga aspek,yaitu privasi, kenyamanan, dan keamanan. Ketiga aspek ini adalah tiga hal yang menjadi pedoman dalam perancangan Pusat Rehabilitasi Gangguan Jiwa dan Skizofrenia.

\subsection{Privasi}

Penataan massa, ruang, dan sirkulasi akan mempengaruhi privasi penderita (Laurens, 2004). Secara tidak langsung, privasi akan memberikan perasaan aman dan nyaman.

Privasi dibagi berdasarkan kebutuhan interaksi penderita. Penderita gangguan jiwa berat membutuhkan privasi yang tinggi, sedangkan penderita gangguan jiwa ringan membutuhkan privasi yang tidak terlalu tinggi untuk mendapatkan interaksi dengan orang lain.

\subsection{Kenyamanan}

Perilaku penderita sangat dipengaruhi oleh kenyamanan dalam suatu bangunan maupun ruangan. Dalam hal ini, kenyamanan yang dimaksud meliputi: penghawaan, pencahayaan, aroma, dan suara.

\subsubsection{Penghawaan}

Suhu dan polusi udara dapat menimbulkan dua efek, yaitu efek kesehatan dan efek perilaku (Holahan, 1982). Pemilihan lokasi yang memiliki udara bersih, dingin, dan polusi udara yang rendah, serta pemilihan bentuk bangunan menjadi fokus perancangan untuk mendapatkan penghawaan yang optimal.

\subsubsection{Pencahayaan}

Pengaturan intensitas cahaya dalam ruangan dapat mempengaruhi kondisi mental penderita. Intensitas cahaya dapat diatur dengan mereduksi cahaya dengan cara dipantulkan dan diberi sekat untuk memfilter cahaya.

\subsubsection{Aroma}

Indra penciuman manusia mempunyai hubungan langsung yang lebih kuat terhapap memori dan emosi daripada panca indra yang lain sehingga mampu mempengaruhi kondisi kejiwaan seseorang. Aroma yang menyenangkan akan memberikan efek positif bagi tubuh, seperti mampu menurunkan tekanan darah dan detak jantung, sedangkan aroma yang menyengat dan tidak menyenangkan akan menimbulkan kegelisahan.

\subsubsection{Kebisingan}

Kebisingan merupakan salah satu pemicu dari perilaku menyimpang pasien gangguan jiwa. Hal ini terjadi karena suara yang tidak menyenangkan atau suara yang ramai membuat otak seseorang terus bekerja tanpa istirahat (Feriadi dan Frick, 2008)

\subsection{Keamanan}

Desain yang aman didapat dari penggunaan interior, material, bentuk, dan tekstur yang tidak mencelakai penderita di dalam bangunan maupun lingkungan sekitarnya (Alread dan Leslie, 2007)

\section{ANALISIS}

Analisis yang digunakan dalam perencanaan dan perancangan Pusat Rehabilitasi Gangguan Jiwa dan Skizofrenia terdiri dari beberapa bagian, yaitu:

\subsection{Analisis Peruangan}

Analisis peruangan didapat berdasarkan kebutuhan dan karakter pengguna serta kegiatan yang dilakukan yang mampu mempengaruhi kejiwaan dan psikologi pengguna. Penggunaan ruang di sini tidak hanya mengacu pada kegiatan secara fisik saja, namun juga secara psikologi (lihat Tabel 1).

Berdasarkan kebutuhan ruang yang ada, diperoleh total luas ruang yang dibutuhkan berdasarkan kelompok kegiatan, yaitu:

1. Kegiatan publik : $3.464,49 \mathrm{~m}^{2}$

2. Kegiatan pengelola : $235,82 \mathrm{~m}^{2}$

3. Kegiatan pelayanan medis: $1.679,19 \mathrm{~m}^{2}$

4. Kegiatan rehabilitasi: $3.195,18 \mathrm{~m}^{2}$

5. Kegiatan rawat inap: $6.794,44 \mathrm{~m}^{2}$

6. Kegiatan servis: $517,66 \mathrm{~m}^{2}$

Tabel 1. Kebutuhan Ruang 


\begin{tabular}{|c|c|}
\hline Publik & $\begin{array}{l}\text { - Ruang Informasi } \\
\text { - Ruang Serbaguna } \\
\text { - Ruang Entertain }\end{array}$ \\
\hline Pengelola & Ruang kerja kepala dan staff \\
\hline $\begin{array}{l}\text { Pelayanan } \\
\text { Medis }\end{array}$ & $\begin{array}{l}\text { - Poliklinik } \\
\text { - Farmasi } \\
\text { - UGD } \\
\text { - Radiologi }\end{array}$ \\
\hline Rehabilitasi & $\begin{array}{l}\text { - Ruang terapi (konseling, } \\
\text { meditasi, terapi kelompok } \\
\text { - Ruang pengembangan diri } \\
\text { (ruang praktek dan ruang } \\
\text { pameran) }\end{array}$ \\
\hline Servis & $\begin{array}{l}\text { - Ruang kerja karyawan } \\
\text { - Ruang penempatan utilitas } \\
\text { bangunan }\end{array}$ \\
\hline
\end{tabular}

\subsection{Analisis Lokasi}

Pemilihan lokasi pusat rehabilitasi harus memperhatikan kondisi lingkungan di sekitarnya. Lingkungan yang alami sangat dibutuhkan oleh pusat rehabilitasi ini.

\subsubsection{Tujuan}

Lokasi yang sesuai dengan pusat rehabilitasi dan pendekatan arsitektur.

\subsubsection{Kriteria pemilihan lokasi}

1. Kesesuaian dengan kebutuhan pusat rehabilitasi.

a. Suasana tenang, beriklim sejuk, dan udara yang bersih sebagai salah satu faktor penunjang kesembuhan.

b. Tingkat kebisingan yang rendah (relatif tenang).

c. Pencapaian yang mudah dijangkau.

d. Faktor pendukung pusat rehabilitasi: fasilitas pendidikan, kesehatan, dan perekonomian.

\section{Luas lahan yang dibutuhkan}

Sesuai dengan perhitungan besaran ruang pada sub bab sebelumnya.

Lokasi terpilih Pusat Rehabilitasi Gangguan Jiwa dan Skizofrenia adalah di Jalan Alternatif Goa Kiskendo, Desa Pendoworejo, Kecamatan Girimulyo, Kabupaten Kulon Progo, Yogyakarta. Luas tapak $\pm 36.200 \mathrm{~m}^{2}$ dengan kondisi tapak yang berkontur sedang. Tapak berbatasan dengan pemukiman dan persawahan di sisi utara dan selatan. Sisi timur berbatasan dengan Jalan Alternatif Goa
Kiskendo $(12 \mathrm{~m})$ dan di sisi barat berbatasan dengan Jalan Wates-Girimulyo (6 m).

\subsection{Analisis Pencapaian}

Pencapaian tapak dibagi menjadi dua, yaitu main entrance dan service entrance yang harus mudah dilihat, mudah diakses dan memiliki sirkulasi yang aman.

\subsubsection{Tujuan}

Main entrane dan service entrance.

\subsubsection{Dasar Pertimbangan}

Perilaku pengguna, kemudahan akses, sirkulasi tapak yang aksesibel, prioritas kegiatan, potensi jalan, dan tingkat keamanan.

\subsubsection{Proses analisis}

\subsubsection{Main Entrance (ME)}

1. Mudah dilihat dan dicapai.

2. Arah kedatangan pengunjung dari jalan utama.

3. Kelancaran lalu lintas.

4. Kegiatan di sekitar tapak.

\subsubsection{Service Entrance (SE)}

1. Tidak mengganggu kegiatan pengunjung.

2. Mendukung kegiatan pengelola, karyawan, dan servis.

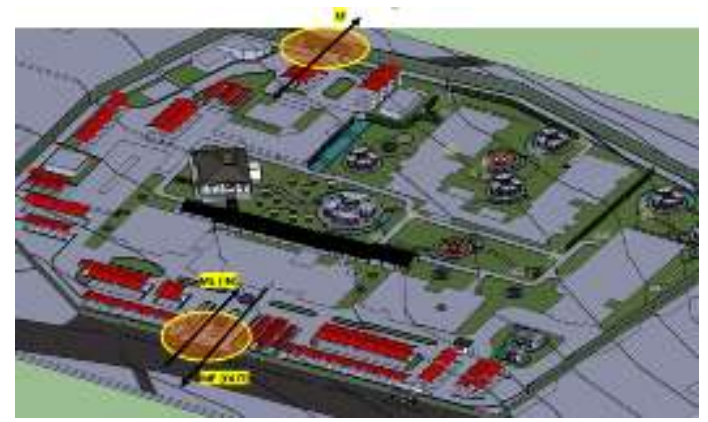

Gambar 1. Analisis Pencapaian

Main entrance (in/out) yang berada di sisi timur digunakan bagi pejalan kaki dan drop off. Pada sisi barat digunakan sebagai service entrance (in/out) untuk kendaraan pengelola, karyawan, dan servis (lihat Gambar 1).

\subsection{Analisis Privasi}

\subsubsection{Tujuan}

Privacy gradient, pemisahan area publik, dan privat.

\subsubsection{Dasar Pertimbangan}

Perilaku pengguna, sumber kebisingan, tingkat keamanan. 


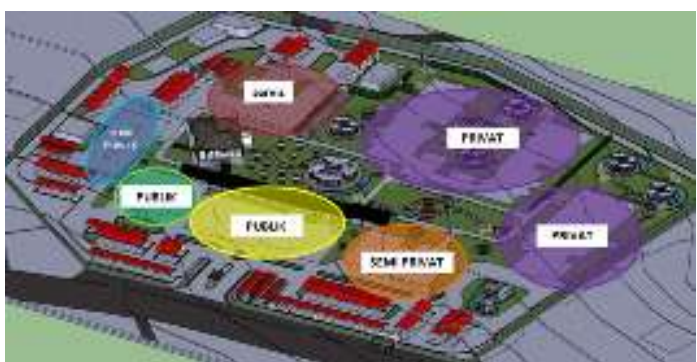

Gambar 2. Privacy Gradient

Privasi didapatkan dengan mengolah sirkulasi dan pola tata bangunan secara berurutan dari area yang paling dekat dengan keramaian hingga area yang paling jauh dari keramaian. Area publik diletakkan di sisi paling depan, dekat dengan main entrance. Area rawat inap diletakkan di sisi belakang dan jauh dari main entrance maupun service entrance (lihat Gambar 2).

\subsection{Analisis Kenyamanan}

Analisis Kenyamanan meliputi klimatologi dan tingkat kebisingan.

\subsubsection{Klimatologi}

\subsubsection{Tujuan}

Arah orientasi, tata ruang, dan tampilan bangunan.

\subsubsection{Dasar Pertimbangan}

1. Perilaku pengguna.

2. Arah edar matahari.

3. Kebutuhan pencahayaan tiap ruang.

4. Keberadaan bangunan sekitar.

5. Arah angin.

Klimatologi digunakan sebagai penentuan bukaan, arah orientasi, tata ruang, dan material yang digunakan sehingga arah angin dan sinar matahari sangat berpengaruh pada perancangan (lihat Gambar 3).

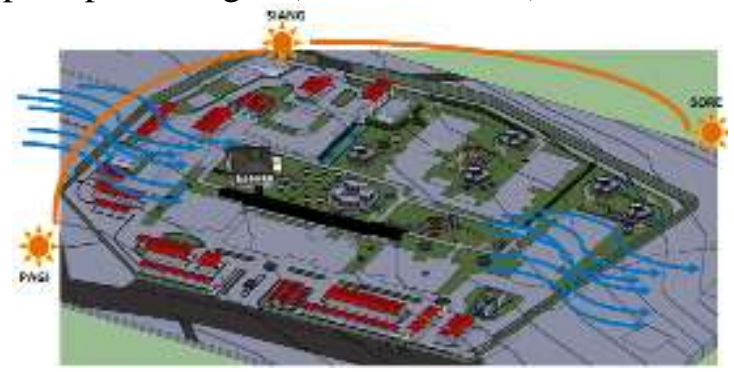

Gambar 3. Analisis Klimatologi

\subsection{Kebisingan}

3.6.1 Tujuan
Tampilan bangunan, pola tata massa, dan lansekap.

\subsubsection{Dasar Pertimbangan}

1. Perilaku pengguna.

2. Letak sumber kebisingan.

3. Kepadatan lalu lintas.

\subsubsection{Hasil analisis:}

Kebisingan tertinggi berada di sisi timur, sedangkan kebisingan terendah berada di sisi utara dan barat sehingga sisi timur dapat digunakan sebagai area publik dan sisi utara dan barat dapat digunakan sebagai area privat (lihat Gambar 4).

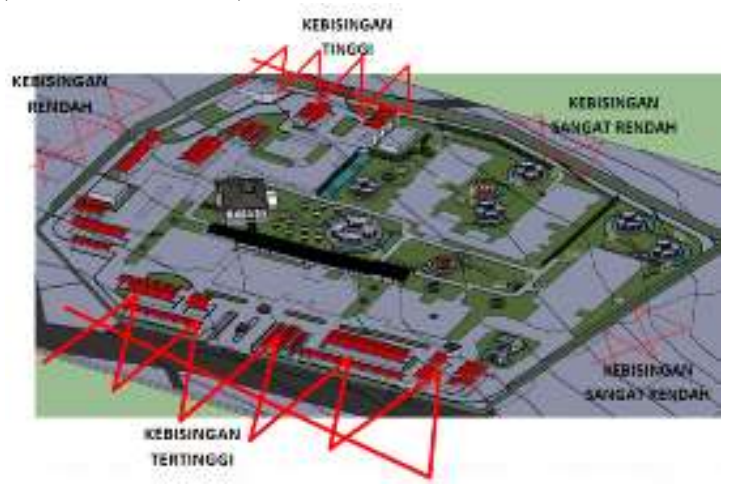

Gambar 4. Analisis Kebisingan

\subsection{Analisis Pemintakatan (Penzoningan)}

Pemintakatan berdasarkan karakter dan jenis kegiatan, serta keadaan tapak dilakukan sebagai acuan dalam penataan peruangan, namun tetap memperhatikan prinsip-prinsip Arsitektur Perilaku.

\subsubsection{Tujuan}

Mintakat (zoning) berdasarkan karakter dan jenis kegiatan dan keadaan tapak.

\subsubsection{Dasar Pertimbangan}

Analisis peruangan, analisis pengolahan tapak, analisis kenyamanan (klimatologi dan kebisingan).

\subsubsection{Proses Analisis}

Persyaratan ruang, berdasarkan kelompok kegiatan dan analisis pengolahan tapak (lihat Gambar 5). 


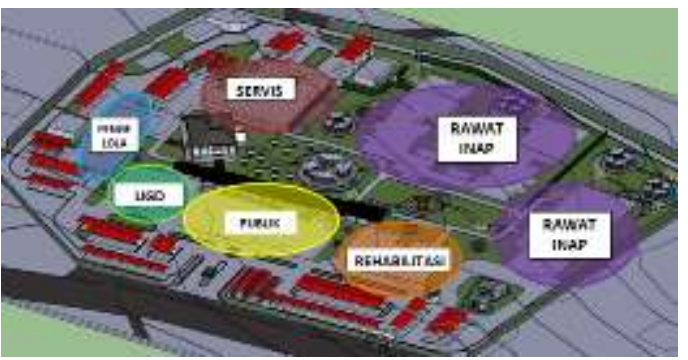

Gambar 5. Analisis Pemintakatan

\subsection{Analisis Bentuk dan Tampilan Bangunan}

Bentuk dasar yang digunakan terdiri dari satu bentuk, yaitu bentuk persegi. Bentuk persegi dipilih karena memiliki sifat dinamis dan efisiensi ruang yang tinggi sehingga dapat mewadahi sebagian besar kegiatan. Terdapat pengurangan dan penambahan di beberapa bagian yang telah disesuaikan dengan fungsi dari masing-masing bangunan. Bentuk persegi ini kemudian dikombinasikan dengan atap limasan dan miring untuk memberikan kesan homey sehingga bangunan tidak terlihat terlalu formal dan kaku.

Penyusunan tata bangunan dibuat terpusat dengan taman yang berada di tengah sebagai pusatnya. Tujuan penerapan tata bangunan terpusat adalah untuk meningkatkan kemudahan dalam interaksi sosial, baik interaksi manusia dengan manusia, interaksi manusia dengan bangunan, maupun interaksi manusia dengan alam (lihat Gambar 6).

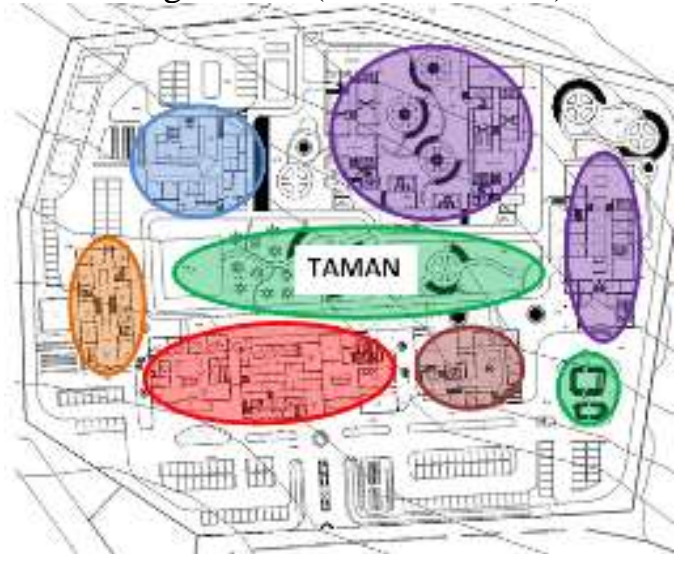

Gambar 6. Pola Tata Bangunan Terpusat

Kriteria Tampilan Bangunan

1. Sesuai dengan fungsi, tidak terlalu kompleks, namun tetap disesuaikan dengan peilaku pengguna.
2. Elemen estetika bangunan tetap memperhatikan privasi, keamanan, dan kenyamanan pengguna.

3. Penggunaan warna natural yang sesuai dengan kebutuhan psikologis penderita.

Suasana pusat rehabilitasi yang homey, namun tetap berprinsip pada privasi, keamanan, dan kenyamanan menjadi fokus utama perancangan pusat rehabilitasi (lihat Gambar 7).

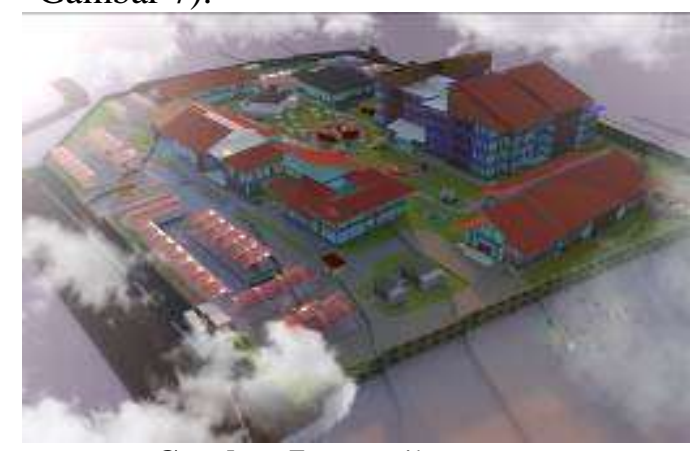

Gambar 7. Tampilan Bangunan

\subsection{Analisis Interior Ruang}

Pada analisis interior ruang terdapat beberapa prinsip Arsitektur Perilaku yang diterapkan, yaitu prinsip privasi, kenyamanan (penghawaan, pencahayaan, kebisingan, material, dan aroma), dan keamanan (material dan perabot).

Prinsip Arsitektur Perilaku tersebut diaplikasikan pada tiap ruang, namun pada beberapa ruang prinsip ini sangat dibutuhkan karena fungsi dan kegiatan yang terdapat di dalamnya. Ruang-ruang tersebut adalah ruang tunggu, kamar rawat inap, kamar isolasi, dan koridor area pelayanan medis.

\subsubsection{Ruang Tunggu}

Di ruang tunggu ini terdapat dua jenis pengguna yang perlu diperhatikan perilakunya, yaitu penderita dan pengunjung. Bagi pengunjung, fasilitas kesehatan jiwa merupakan suatu tempat yang menakutkan dan memalukan. Begitu pula bagi sebagaian penderita. Banyak penderita yang berteriakteriak membuat kebisingan saat berada di tempat umum. Hal ini menjadi salah satu penyebab yang membuat pengguna dan penderita lainnya merasa kurang nyaman dan tidak aman. Untuk menangani hal tersebut, dibutuhkan sebuah ruang tunggu yang tertutup tapi tidak memberikan kesan mengurung bagi 
pengunjung dan penderita yang memiliki urusan di area pelayanan medis.

Berikut suasana dan aplikasi desain yang hendak dicapai (lihat Tabel 2):

Tabel 2. Perancangan Suasana Ruang Tunggu

\begin{tabular}{|l|l|}
\hline Suasana & Aplikasi Desain \\
\hline $\begin{array}{l}\text { Tenang, } \\
\text { rileks, } \\
\text { hangat }\end{array}$ & $\begin{array}{l}\text { Penataan cahaya buatan } \\
\text { warna kekuningan, } \\
\text { pengaturan intensitas } \\
\text { sinar matahari dengan } \\
\text { secondary scene. }\end{array}$ \\
\hline $\begin{array}{l}\text { Sejuk, } \\
\text { nyaman, } \\
\text { tenang }\end{array}$ & $\begin{array}{l}\text { Bukaan dan vegetasi } \\
\text { sebagai filter udara di } \\
\text { dalam maupun luar } \\
\text { ruang. }\end{array}$ \\
\hline $\begin{array}{l}\text { Sepi, } \\
\text { rileks, } \\
\text { meredakan } \\
\text { stres }\end{array}$ & $\begin{array}{l}\text { Vegetasi dan roster } \\
\text { tanaman di sekitar ruang, } \\
\text { dinding partisi sebagai } \\
\text { peredam suara, aroma } \\
\text { terapi di dalam maupun } \\
\text { luar ruang. }\end{array}$ \\
\hline $\begin{array}{l}\text { Privasi } \\
\text { terlindungi }\end{array}$ & $\begin{array}{l}\text { Pemisahan ruang tunggu } \\
\text { pengguna satu dengan } \\
\text { yang lainnya. }\end{array}$ \\
\hline $\begin{array}{l}\text { Merasa } \\
\text { aman }\end{array}$ & $\begin{array}{l}\text { Lantai tidak licin, } \\
\text { pembatas pada bukaan. }\end{array}$ \\
\hline
\end{tabular}

Privasi pengguna diwujudkan dalam rancangan ruang tunggu yang yang dibuat tertutup dan terpisah (lihat Gambar 8 dan 9).

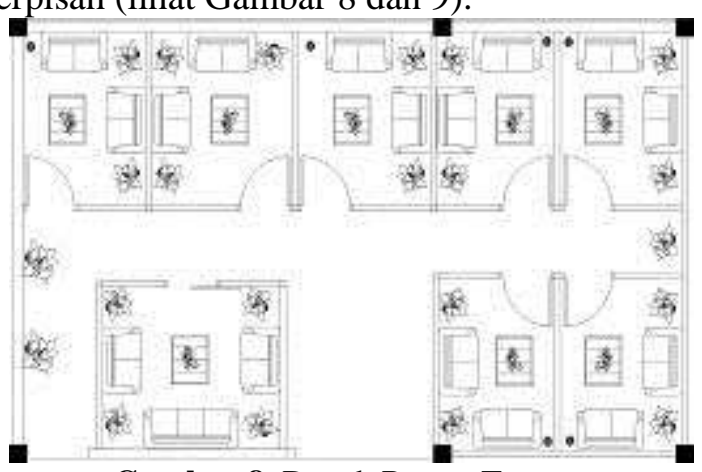

Gambar 8. Denah Ruang Tunggu

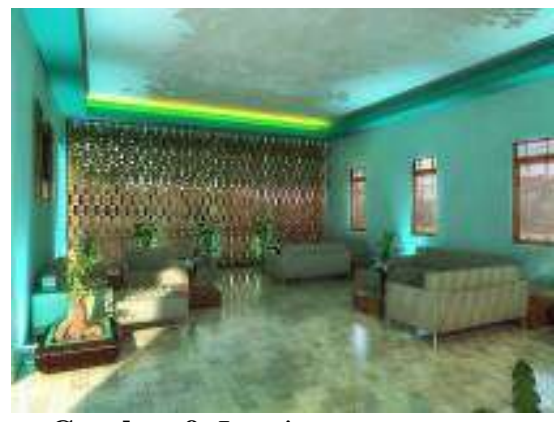

Gambar 9. Interior ruang tunggu
Penggunaan warna yang soft, seperti warna biru, coklat, dan kuning memberikan kesan lembut dan rileks pada ruangan. Membuat pengguna menjadi lebih tenang dan tidak stres (lihat Gambar 9).

\subsubsection{Koridor Area Pelayanan}

Koridor area pelayanan merupakan akses untuk menuju ke masing-masing fasilitas pelayanan medis. Memiliki kegiatan yang cukup mengganggu karena letaknya yang dekat dengan area pelayanan seperti poliklinik, farmasi, radiologi, dan UGD yang sering dilewati pengguna (lihat Gambar 10).

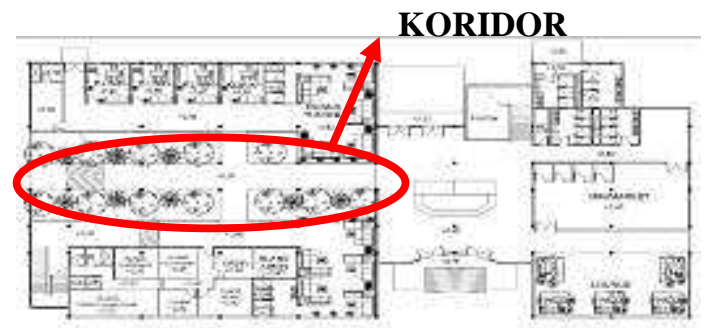

Gambar 10. Denah Koridor Area Pelayanan Medis di Bangunan Publik

Kebisingan menjadi salah satu hal yang paling mengganggu bagi kegiatan di ruang-ruang sekitar koridor. Diperlukan filter kebisingan dengan memanfaatkan elemen alam di sekitarnya. Filter tersebut berupa peletakkan roster tanaman untuk menghalangi pandangan pengguna koridor ke area pelayanan medis serta pemberian vegetasi dan kolam yang berguna untuk memberikan suasana yang natural dengan suara-suara alam yang berasal dari kolam dan vegetasi (lihat Gambar 11).

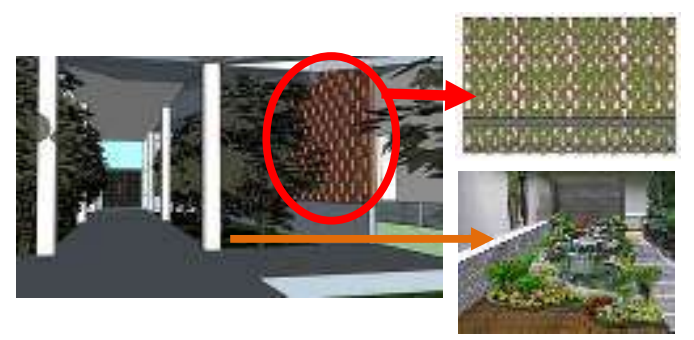

Gambar 11. Aplikasi Roster Tanaman dan

Vegetasi pada Koridor Pelayanan Medis

\subsubsection{Kamar Rawat Inap}

Penderita gangguan jiwa berbeda dengan penderita penyakit fisik. Mereka membutuhkan perlakuan khusus untuk dapat sembuh. Hal ini diterapkan pada kamar rawat inap penderita gangguan jiwa. Kamar rawat inap penderita 
gangguan ringan dibagi menjadi tiga. Perbedaan hanya pada jumlah ranjang dalam satu kamar dan terapi yang dibutuhkan.

Kamar dengan ranjang yang lebih sedikit, penderita baru dapat berinteraksi dengan orang lain dalam jumlah tertentu. Begitu pula sebaliknya pada kamar dengan ranjang yang lebih banyak, penderita dapat memulai rehabilitasi sosial dan berinteraksi dengan orang lain lebih banyak dan lebih sering (lihat Gambar 12 dan 13).

Berikut suasana dan aplikasi desain yang hendak dicapai (lihat Tabel 3).

Tabel 3. Perancangan Suasana Kamar Rawat Inap

\begin{tabular}{|l|l|}
\hline Suasana & Aplikasi Desain \\
\hline $\begin{array}{l}\text { Tenang, } \\
\text { rileks, } \\
\text { hangat }\end{array}$ & $\begin{array}{l}\text { Penataan cahaya buatan warna } \\
\text { kekuningan, mementulkan } \\
\text { cahaya agar tidak langsung } \\
\text { mengenai penderita. }\end{array}$ \\
\hline $\begin{array}{l}\text { Rileks, } \\
\text { meredakan } \\
\text { stres }\end{array}$ & $\begin{array}{l}\text { Pemasangan dinding partisi } \\
\text { peredam suara pemberian } \\
\text { aroma terapi }\end{array}$ \\
\hline $\begin{array}{l}\text { Tidak } \\
\text { merasa } \\
\text { terkurung, }\end{array}$ & $\begin{array}{l}\text { Roster tanaman pengganti } \\
\text { dinding tidak memberikan } \\
\text { kesan mengurung. }\end{array}$ \\
\hline $\begin{array}{l}\text { Merasa } \\
\text { aman }\end{array}$ & $\begin{array}{l}\text { Lantai tidak licin, bukaan dibuat } \\
\text { tinggi } \pm \text { 1,5 m di atas } \\
\text { permukaan tanah, interior dari } \\
\text { bahan lunak dan tidak bersudut, } \\
\text { interior bersudut diberi } \\
\text { pelindung karet/busa, plafon } \\
\text { dibuat tinggi. }\end{array}$ \\
\hline
\end{tabular}

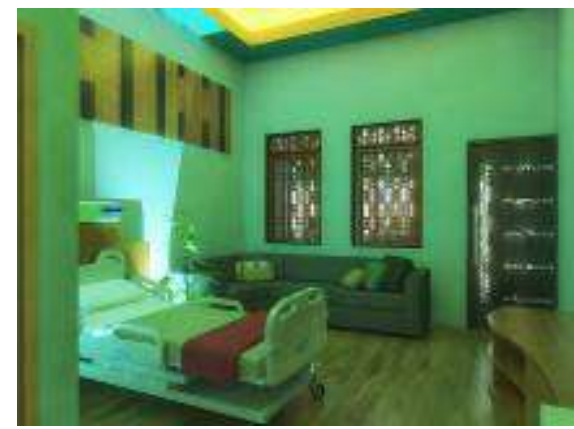

Gambar 12. Interior Kamar Rawat Inap 1 Ranjang

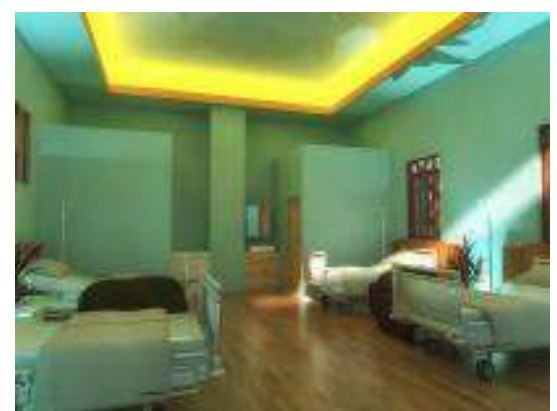

Gambar 13. Interior Kamar Rawat Inap 4 Ranjang

\subsubsection{Kamar Isolasi}

Penderita gangguan jiwa berat memerlukan perawatan dan kamar khusus karena mereka memiliki masalah mental yang sangat parah. Penderita gangguan jiwa sering merasa terancam, ketakutan, mengamuk, dan tidak bisa mengendalikan emosi. Tidak sedikit juga penderita yang berniat mencelakakan diri.

Interior kamar isolasi mendapat perlakuan khusus lebih dari interior kamar rawat inap. Hal ini disebabkan karena penderita memiliki potensi untuk melakukan hal-hal yang membahayakan (lihat Gambar 14).

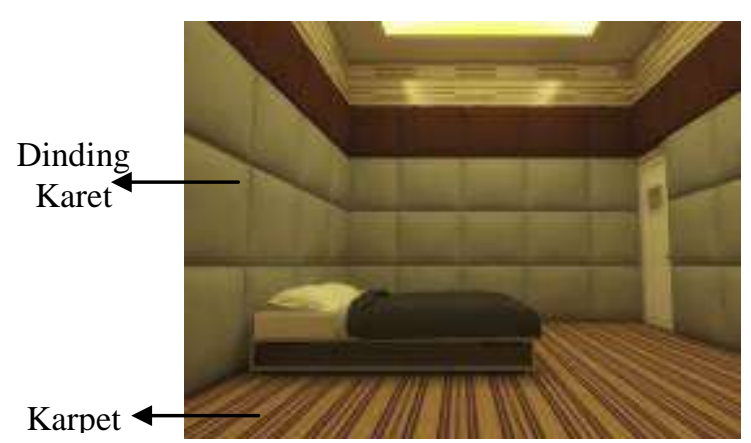

Gambar 14. Interior Kamar Isolasi

Berikut suasana dan aplikasi desain yang hendak dicapai (lihat Tabel 4).

Tabel 4. Perancangan Suasana Kamar Isolasi

\begin{tabular}{|l|l|}
\hline \multicolumn{1}{|c|}{ Suasana } & \multicolumn{1}{c|}{ Aplikasi Desain } \\
\hline $\begin{array}{l}\text { Tenang, } \\
\text { rileks, } \\
\text { hangat }\end{array}$ & $\begin{array}{l}\text { Penataan cahaya buatan } \\
\text { warna kekuningan, } \\
\text { mementulkan cahaya } \\
\text { agar tidak langsung } \\
\text { mengenai penderita. }\end{array}$ \\
\hline $\begin{array}{l}\text { Sepi, } \\
\text { rileks, } \\
\text { meredakan } \\
\text { stres }\end{array}$ & $\begin{array}{l}\text { Pemasangan dinding } \\
\text { partisi peredam suara, } \\
\text { pemberian aroma terapi }\end{array}$ \\
\hline $\begin{array}{l}\text { Merasa } \\
\text { aman }\end{array}$ & $\begin{array}{l}\text { Lantai tidak licin, bukaan } \\
\text { dibuat tinggi } \pm 1,5 \mathrm{~m} \text { di } \\
\text { atas permukaan tanah, }\end{array}$ \\
\hline
\end{tabular}




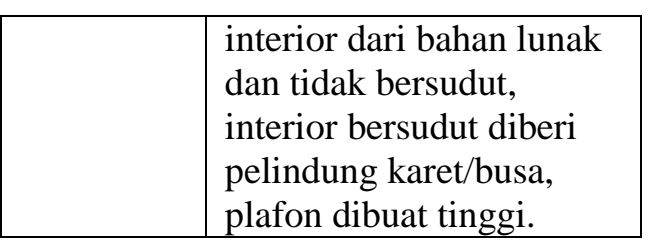

\section{KESIMPULAN (KONSEP DESAIN)}

Pusat Rehabilitasi Gangguan Jiwa dan Skizofrenia direncanakan sebagai fasilitas kesehatan jiwa yang tidak hanya berfokus pada pengobatan secara medis, namun juga secara non medis. Pengobatan non medis merupakan pengobatan dengan cara terapi dan interaksi sosial. Pusat rehabilitasi ini direncanakan di daerah Pendoworejo, Kecamatan Girimulyo, Kabupaten Kulon Progo, Yogyakarta.

Desain perancangan pusat rehabilitasi ini diwujudkan dengan pendekatan Arsitektur Perilaku yang diaplikasikan pada hampir semua bagian terutama pada konsep peruangan dan tampilan bangunan.

Pendekatan Arsitektur Perilaku dalam sebagian besar perancangan berfokus pada tiga aspek, yaitu privasi, kenyamanan, dan kemanan.

\subsection{Privasi}

Privasi diaplikasikan pada pusat rehabilitasi untuk memberikan rasa aman dan nyaman secara mental bagi para pelaku kegiatan. Dalam desain, privasi didapat dari sirkulasi dan pencapaian, penataan massa bangunan, dan penataan ruang.

Pada tampilan bangunan juga terdapat beberapa komponen, seperti aplikasi roster,

tanaman, dan vegetasi yang cukup tinggi sebagai penghalang penglihatan dari luar (lihat Gambar 15).

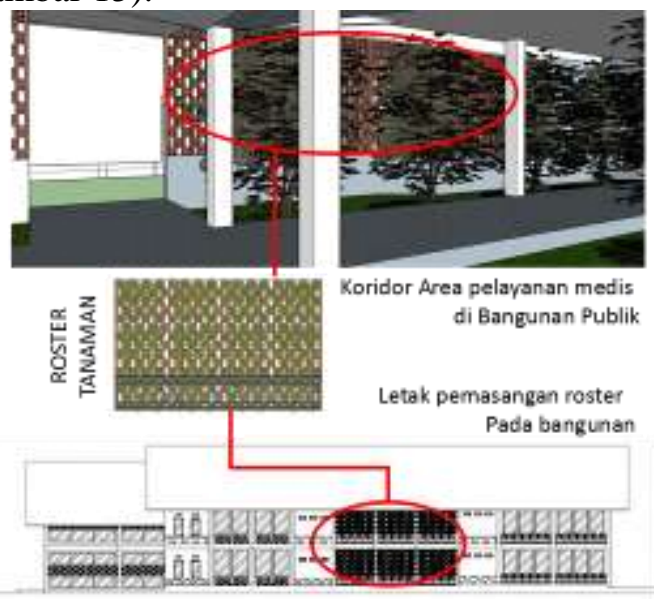

Gambar 15. Aplikasi Roster pada Interior Ruang dan Tampilan Bangunan

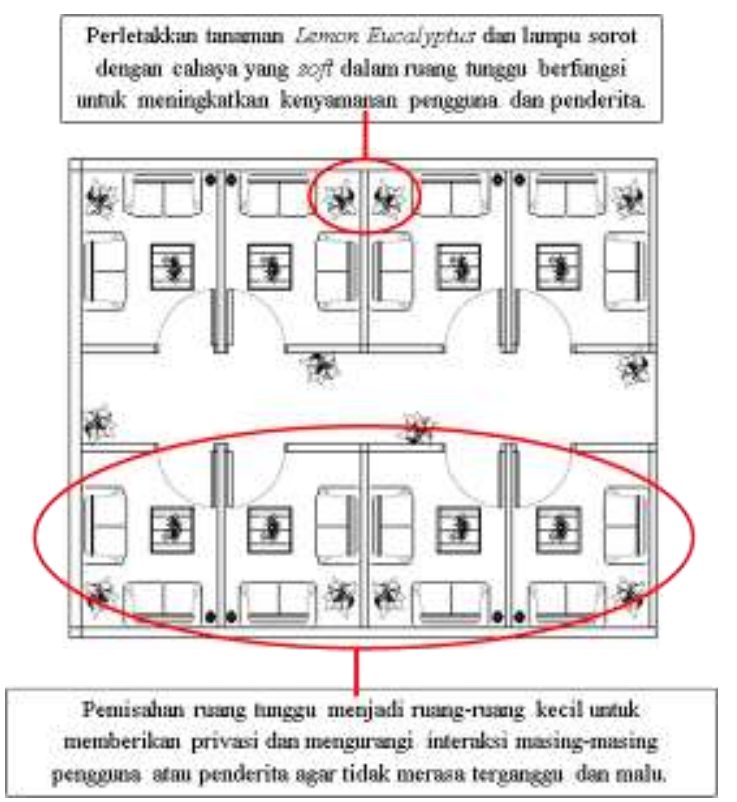

Gambar 16. Denah Interior Ruang Tunggu

\subsection{Kenyamanan}

Kenyamanan dalam bangunan didapat dari respon desain terhadap kebisingan, pencahayaan, penghawaan, dan aroma. Aplikasi desain bangunan yang nyaman pada pusat rehabilitasi ditunjukkan dengan penataan ruang dan tampilan bangunan yang telah disesuaikan dengan kebutuhan dan perilaku yang ditampilkan pengguna.

Desain penataan ruang yang sesuai dengan arsitektur perilaku ditunjukkan interior ruang pada bangunan rawat inap dan bangunan VIP (lihat Gambar 17).

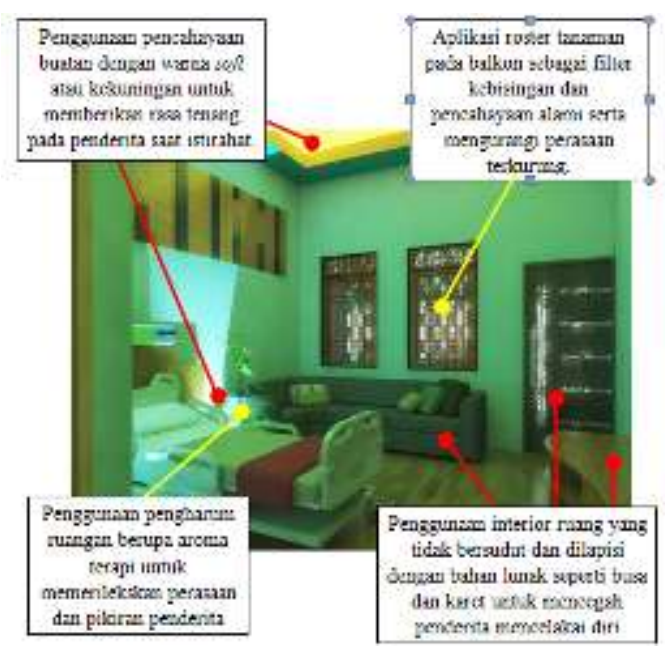

Gambar 17. Penerapan Arsitektur Perilaku pada Kamar Rawat Inap

\subsection{Keamanan}


Desain yang didapat dari aspek keamanan diaplikasikan pada pengolahan tapak, interior, dan tampilan bangunan. Desain dirancang secara khusus terutama pada desain interior karena desain harus dapat memenuhi kebutuhan dan mencegah pengguna membahayakan diri sendiri dan orang lain (lihat Gambar 18 dan 19).

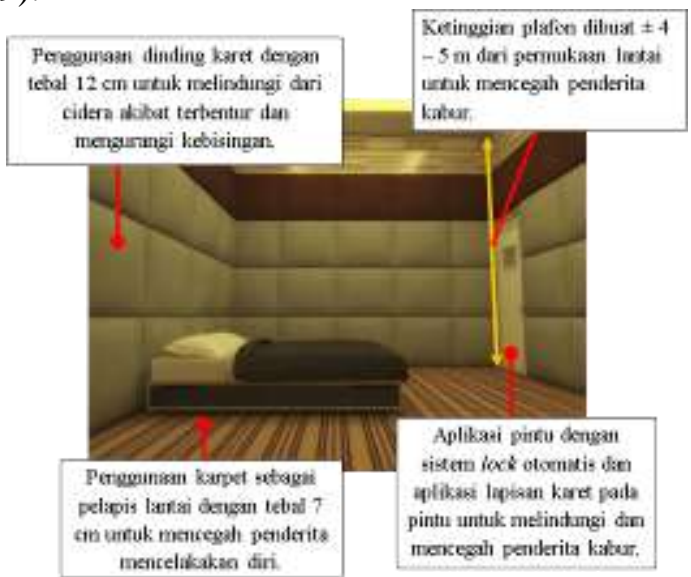

Gambar 18. Interior Kamar Isolasi
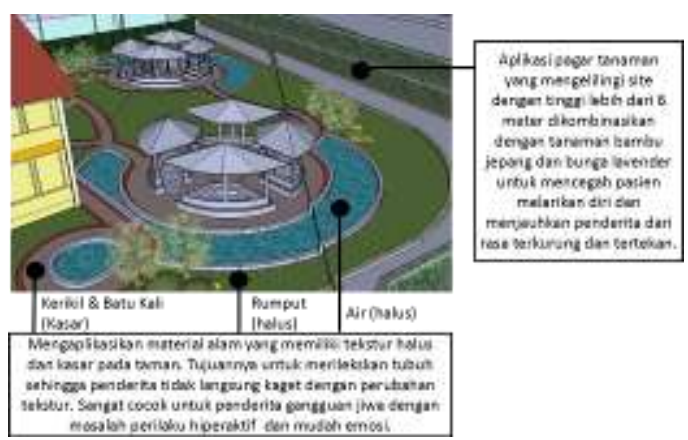

Gambar 19. Eksterior Bangunan

\section{REFERENSI}

Alread, Jason dan Thomas Leslie. 2007. Design Tech: Building Science for Architect. London: Elseiver, Linacre House, Jordan Hill, Oxford.

Gifford, Robert (2007). Environmental Psychology: Principles and Practice (5th ed.). Colville, WA: Optimal Books. p. 599.

Feriadi, Henry dan Heinz Frick. 2008. Atap Bertanaman Ekologis dan Fungsional. Yogyakarta: Penerbit Kanisius.

Holahan , Charles J. 1982. Environmental Psychology. Random House, Inc.

Laurens, Joyce M. 2004. Arsitekttur dan Perilaku Manusia. Jakarta: Grasindo. Pemerintah Daerah Istimewa Yogyakarta. 2013. Data Riset Kesehatan Dasar Propinsi DIY. Yogyakarta: Pemerintah Propinsi Daerah Istimewa Yogyakarta.

Pemerintah Daerah Istimewa Yogyakarta. 2013. Profil RS Jiwa Ghrasia DIY. Yogyakarta. grhasia.jogjaprov.go.id/. (Diakses pada tanggal 17 Maret 2016) 